\title{
Analysis of Xylem Fluid Components in Almond Cultivars Differing in Resistance to Almond Leaf Scorch Disease
}

\author{
Margot Wilhelm, Department of Plant Pathology University of California, Davis 95616; Brent V. Brodbeck and Peter C. Andersen, \\ University of Florida, North Florida Research and Education Center, Quincy, 32353; George W. Kasun and Bruce C. Kirkpatrick, \\ Department of Plant Pathology University of California, Davis
}

\begin{abstract}
Wilhelm, M., Brodbeck, B. V., Andersen, P. C., Kasun, G. W., and Kirkpatrick, B. C. 2011. Analysis of xylem fluid components in almond cultivars differing in resistance to almond leaf scorch disease. Plant Dis. 95:166-172.

Almond leaf scorch (ALS) is caused by the pathogenic bacterium $X y$ lella fastidiosa and poses a threat to the California almond industry. Almond cultivars are differentially resistant or susceptible to ALS. X. fastidiosa can infect but does not overwinter in resistant cultivars in sufficient numbers to cause symptoms or be detected by polymerase chain reaction. To better understand the biochemical or morphological factors mediating resistance, we extracted and analyzed almond xylem fluid from four almond cultivars differing in ALS susceptibility, including Butte and Carmel cultivars that are field resistant and Peerless and Sonora that are ALS susceptible. Xylem fluid was collected over winter months in 2007 to 2009, as well as July 2008 and April 2009, and

analyzed for the following: $\mathrm{pH}$, osmolarity, concentrations of sugars, calcium, magnesium, organic acids, and total phenolics. For most of these analyses, we found no clear differences in xylem fluid from resistant and susceptible almond cultivars. However, during the winter months, resistant cultivars tended to have higher concentrations of total phenolic compounds compared with susceptible cultivars $(P=0.05)$. In February 2009, Carmel had the highest total phenolic concentration measured, $233 \mu \mathrm{g} / \mathrm{ml}$ of gallic acid equivalents. The lowest phenolic concentrations occurred in April 2009. The cross-sectional areas of xylem vessels in Butte (resistant) and Peerless (susceptible) trees were not significantly different between cultivars.
\end{abstract}

Almond leaf scorch (ALS) was first identified in California in the 1950s near Los Angeles and in Contra Costa County (30). At the time, the disease was known as the "Golden Death" because of its characteristic leaf yellowing and scorching symptoms (30). Currently, the disease has been reported in all main almondgrowing regions of California, including Butte, Chico, Kern, and Fresno Counties. ALS is caused by the gram-negative, rod-shaped bacterium, Xylella fastidiosa. X. fastidiosa inhabits only the plant xylem and the foreguts of xylem-feeding insect vectors. Strains of $X$. fastidiosa cause several other crop diseases, such as Pierce's disease (PD) of grapevine, citrus variegated chlorosis, alfalfa dwarf, and phony peach disease (28). In almond trees and other hosts, the main symptom is leaf scorching beginning at leaf margins, with a yellow or orange halo preceding the dry, necrotic leaf margin. Other symptoms include poor leaf set, significant tree decline over 3 to 8 years (26), and decreased almond yields (33).

$X$. fastidiosa is known to infect a very broad host range, including grapevine, citrus, almond, peach, oleander, coffee, mulberry, plum, oak, and many other dicot and monocot hosts $(2,13,18,28,32)$. Strain groupings of $X$. fastidiosa are primarily based on host specificity and genetic properties. Three genetically different $X$. fastidiosa strains have been found in almond (17), including one almond group that can also cause PD and two other groups that are specific to almond. In greenhouse experiments, Almeida and Purcell (3) showed that more grape strains could cause PD and ALS, whereas only a few almond strains could elicit PD symptoms. There are cases where both grape and almond strains of $X$. fastidiosa have been simultaneously isolated form ALS-infected trees (12).

Corresponding author: B. C. Kirkpatrick

E-mail: bckirkpatrick@ucdavis.edu

Accepted for publication 13 September 2010.

doi:10.1094/PDIS-05-10-0328

(C) 2011 The American Phytopathological Society
Like all diseases caused by $X$. fastidiosa, ALS is vectored by xylem-feeding insects. The green sharpshooter, Draeculacephala minerva, is the main vector in California (34), although other sharpshooters and spittlebugs can transmit $X$. fastidiosa to almond. Infection within almond orchards is often clustered, and more prevalent in border rows (15). Because ALS spread from almond tree to almond tree is considered negligible (27), most infections are probably transferred from nearby areas, such as weedy alfalfa fields that are known to harbor large populations of insect vectors (34). It is possible that insect vectors also acquire and transmit $X$. fastidiosa from alternate weed hosts within or bordering the orchard (31).

Several studies have indicated a range of susceptibility to ALS among different almond cultivars. NonPareil and Sonora cultivars are reported as most susceptible while Butte, Carmel, Mission, Fritz, and Thompson are considered moderately resistant $(15,16)$. $\mathrm{Cao}$ et al. (11) found that, for 10 almond cultivars tested, trees mechanically inoculated in June 2002 developed ALS symptoms 6 to 10 weeks later. When symptoms were rated in autumn 2003, some cultivars had no disease symptoms, indicating that the $X$. fastidiosa infection had not overwintered in sufficient populations to cause disease no be detected by polymerase chain reaction (PCR). In assessments of the same trees 2 to 8 years later, no ALS symptoms were observed in cvs. Butte, Carmel, Thompson, or Padre and all these trees tested negatively by PCR for $X$. fastidiosa. Hence, resistance or susceptibility may depend on $X$. fastidiosa's ability to survive inside the xylem elements over the winter. These results are intriguing. $X$. fastidiosa in grapevines may be eradicated by a cold-curing phenomenon that occurs when dormant grapevines experience temperatures below $10^{\circ} \mathrm{C}$ (14). Feil and Purcell found that populations of $X$. fastidios $a$ in grape seedlings declined 160 -fold after 15 days at $5^{\circ} \mathrm{C}$ (14). Conversely, Kirkpatrick and Meyer observed that $X$. fastidiosa could survive up to 8 weeks in artificial media at $-5^{\circ} \mathrm{C}(19)$. These results suggest that some components of the xylem fluid in planta may be affecting $X$. fastidiosa survival (19).

In addition to the cold-curing effect, different grape cultivars and species also have differing resistance or susceptibility to PD. Although the mechanisms of resistance are not clear, xylem fluid 
chemistry affects $X$. fastidiosa's growth, cell aggregation, and biofilm formation $(4,6,8,22,23)$. Andersen et al. (7) found that the ratios of $\mathrm{Ca}^{+}, \mathrm{Mg}^{+}$, phosphate, and citric acid could be correlated with the relative resistance or susceptibility to PD in grapevine. Susceptible grape cultivars had higher free $\mathrm{Ca}^{+}$concentrations and, in artificial medium, higher $\mathrm{Ca}^{+}$induced $X$. fastidiosa cell aggregation. Lower $\mathrm{pH}$ was found to increase the amount of free calcium in xylem fluid (22). Because biofilm formation is a pathogenicity factor for $X$. fastidiosa, xylem chemistry could affect $X$. fastidiosa survival in almond over the winter.

The objectives for this research were to analyze certain constituents of xylem fluid chemistry from healthy, ALS-susceptible and ALS-resistant almond cultivars during the winter months. Analyses were performed on grapevine xylem fluid in relation to the coldcuring phenomenon of PD (19); therefore, we chose a similar approach. We hypothesized that, if any particular xylem fluid constituents were mediating the winter killing of $X$. fastidiosa, we should see either quantitative or qualitative differences in these factors between resistant and susceptible almond cultivars. Our analysis of different components and properties of xylem fluid are the first presented for almond, and will serve as the basis for further research.

\section{Materials and Methods}

Almond cultivars and isolation of xylem fluid from almond branches. Two ALS-susceptible almond cultivars (Peerless and Sonora) and two semi-ALS-resistant almond cultivars (Butte and Carmel) were chosen for this study. Sonora is the most ALS susceptible, followed by Peerless, while Butte and Carmel are the most ALS resistant $(15,16)$. We chose to only examine healthy trees because we did not want the xylem sap modified in any manner by infection with $X$. fastidiosa. We also felt that there would be no value in monitoring $X$. fastidiosa populations in a set of infected trees because it is not possible to culture $X$. fastidiosa from cambial scraping of dormant twigs because of contamination by rapidly growing epiphytic bacteria and fungi. Attempting to assess $X$. fastidiosa populations by PCR would likewise be of little value because PCR can detect the presence of dead X. fastidiosa cells. In 2007, we sampled xylem fluid from two 6-year-old trees of each cultivar growing in the University of California, Davis, Plant Pathology field area. In February 2008, two more trees per cultivar were added to obtain better statistical results.

Xylem fluid was expressed on a monthly basis over winter months. In 2007-08, xylem fluid was collected in November, January, February, March, and July. In 2008-09, xylem fluid was collected in November, December, January, February, March, and April. One to seven almond branches, approximately 50 to $80 \mathrm{~cm}$ long, were cut from each sample tree in the morning. Xylem fluid was expressed from cut almond branches using a specially designed pressure chamber (PMS Instruments, Corvallis, OR). The end of the branch protruding from the pressure chamber was wiped with $70 \%$ ethanol to reduce particulates that can fall into the collection tubes. The first few microliters of liquid were discarded to avoid collecting wound exudate and cellular constituents. Collection tubes containing expressed xylem fluid were put directly on ice to slow any oxidation process. Typically, 100 to $1,000 \mu$ l (late winter and spring only) of fluid per branch was collected. Xylem samples were stored at $-20^{\circ} \mathrm{C}$ for later use.

pH and osmolarity measurements. On the same day that xylem was extracted, three $\mathrm{pH}$ measurements were made of the expressed xylem fluid, collected from at least three branches from each tree (Corning $\mathrm{pH}$ meter 140). These measurements were averaged to obtain a $\mathrm{pH}$ value for xylem fluid from each sample tree. Two to three osmolarity measurements per tree per month were made using a model 5500 vapor pressure osmometer (Wescor Inc., UT). The osmolarity of the November 2008 samples was not measured because the osmometer was not functioning properly.

Analysis of sugars, minerals, and organic acids. Xylem fluid samples were sent to the Agriculture and Natural Resources Analytical Laboratory at the University of California, Davis for analy- sis of fructose, glucose, sucrose, calcium, and magnesium concentrations. Almond xylem fluid $(20 \mu \mathrm{l})$ was submitted for total sugars. These samples were extracted by hot deionized water and analyzed by high-performance liquid chromatography (HPLC) with mass selective detection using a Phenomenex Luna NH2 (250 by $4.6 \mathrm{~mm}$ ) HPLC column at a flow rate of $2.75 \mathrm{ml} / \mathrm{min}$ acetonitrile:water (78:22). Then, 30- $\mu$ l samples submitted for calcium and magnesium analysis were diluted with deionized water and analyzed using inductively coupled plasma atomic emission spectrometry.

Almond xylem fluid samples from 2007-08 (100 $\mu \mathrm{l}$ each) were sent to the Analytical Laboratory at Florida State University for analysis of organic acids (citric, oxalic, malic, malonic, and tartaric acid). Prior to analysis, xylem samples were filtered through 10,000-MW filters. Separation and quantification of organic acids was accomplished by cation exchange chromatography. Injection volumes $(20 \mu \mathrm{l})$ of each sample in 0.015 normal sulfuric acid buffer were run isocratically at $37^{\circ} \mathrm{C}$ through an Ion-300 polymeric column on a Waters 600 HPLC system $(9,10)$.

Folin-Ciocalteau method for total phenols. Total concentration of phenolic compounds in xylem fluid was measured using a modified Folin-Ciocalteau micro method $(35,36)$, which allows the analysis of only $120 \mu \mathrm{l}$ of xylem fluid. Three Folin's reactions were made for each almond xylem fluid sample in 1-ml microcentrifuge tubes. Then, $200 \mu \mathrm{l}$ of each reaction was placed into a 96-well polystyrene plate and the absorbance of the sample was read using a microplate reader at $765 \mathrm{~nm}$ (Molecular Devices, CA). The final concentration of phenolic compounds for each almond fluid sample was calculated as the average of the three Folin's reactions. Total phenolic concentrations of fluid samples were derived from a standard curve using gallic acid standards with known concentrations. All Folin-Ciocalteau measurements are reported as micrograms of gallic acid equivalents (GAE) per milliliter of xylem fluid.

Thin-section vessel measurements. Four 3.5-year-old Butte (ALS-resistant) and Peerless (ALS-susceptible) trees were chosen for xylem vessel measurements. Sampling from these trees occurred every 2 months when one branch from each tree was cut. Cut branches were 1.1 by $1.9 \mathrm{~cm}$ in diameter at the base. Free-hand thin sections were made using razor blades and samples were taken from four locations: (i) the base of the branch, (ii) $5 \mathrm{~cm}$ from the base, (iii) $10 \mathrm{~cm}$ from the base of the branch, and (iv) $15 \mathrm{~cm}$ from the base. Sections were stained with Toludine Blue O, pH 4.4. Toludine blue $\mathrm{O}$ stains primary and secondary cell walls and, thus, stains phloem pinkish-red and xylem elements blue-green. Stained thin sections were observed using bright field microscopy at $\times 200$ magnification. Xylem vessels were morphologically identified and digital pictures taken. Almond wood has two types of xylem vessels: spring and summer. Spring vessels are significantly bigger than summer vessels, facilitating better water transport in the spring. Vessels made in the summer or winter are smaller but more numerous; thus, we measured the two vessel groups separately.

Digital pictures of xylem vessels were analyzed using Image $\mathbf{J}$ (http://rsbweb.nih.gov/ij/index.html) (1). The areas of 10 to 17 vessels of each spring and summer type from each location along the branch were measured. These measurements were averaged to obtain a final average for spring vessel area and summer vessel area for each tree and month of sampling.

Data analysis. Statistical analyses were carried out using the "Analyst" application included in SAS 9.1. The same, separate statistical analysis was done for each xylem fluid component that was measured, including $\mathrm{pH}$, osmolarity, glucose, sucrose, fructose, calcium, magnesium, individual organic acids, and total phenolic compounds. Each measured component was analyzed using a repeated measures analysis of variance. Within the Analyst application the subject was defined as cultivar-tree number and the repeated variable was month. We used the compound symmetry covariance structure. Effects in the model included cultivar, month, and cultivar-month. Least squares means comparisons with a Tukey's adjustment were carried out to compare averages for each 
almond cultivar with those of others for each sampling month, $P=$ 0.05 . Student's $t$ tests were used to compare spring and summer vessels between Butte and Peerless almond cultivars.

\section{Results}

pH and osmolarity measurements. Average $\mathrm{pH}$ values for all xylem samples were between 5.1 and 6.5. Although $\mathrm{pH}$ values varied across different months, there were no trends indicating significant differences between resistant and susceptible cultivars over the winter (Fig. 1). In April 2009, only Butte and Carmel cultivars had significantly lower $\mathrm{pH}$ than Peerless and Sonora $(P<$ 0.001 and 0.0432 , respectively).

Xylem fluid osmolarity in all cultivars was higher in the spring or summer compared with winter months (Fig. 2). The highest osmolarity measured was in cv. Butte in July 2008. Sugar concentrations for all cultivars were also highest in July 2008, potentially contributing to the elevated osmolarities (Table 1). In most months when sugars were measured, a higher osmolarity was associated

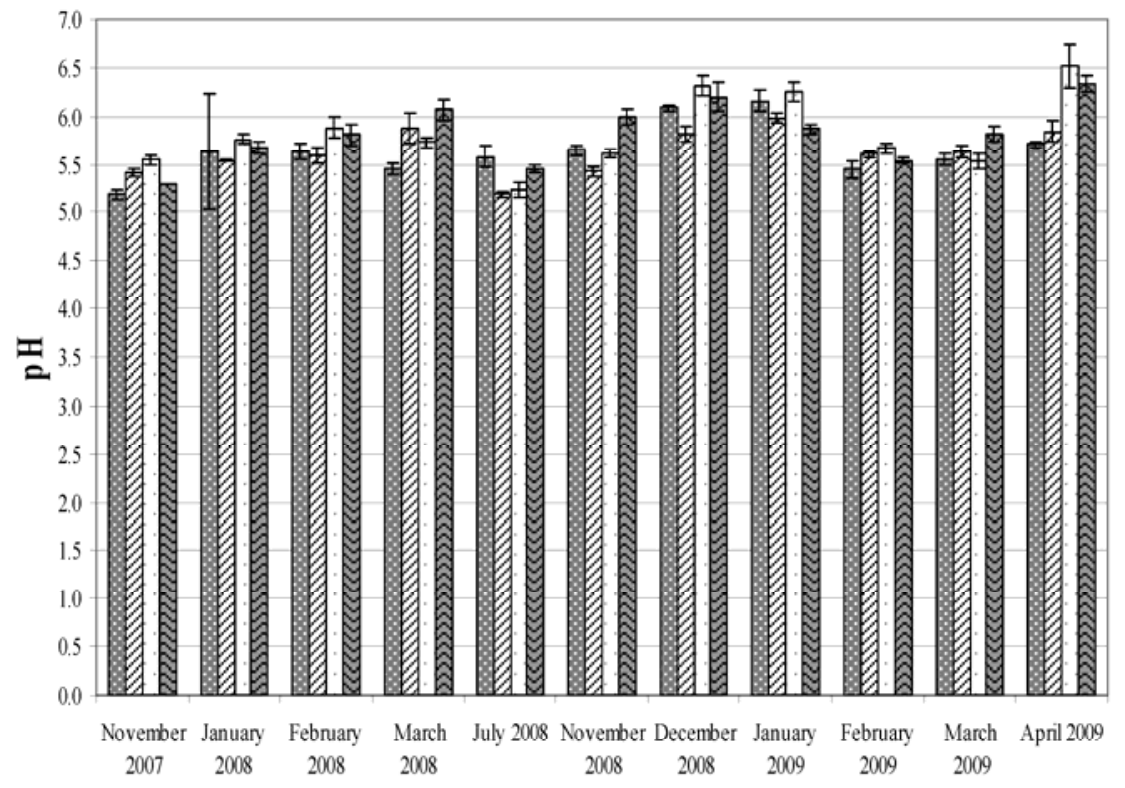

Month

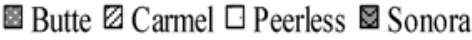

Fig. 1. Average $\mathrm{pH}$ of almond fluid from four almond cultivars sampled over winter and spring 2007 to 2009 , including July 2008. Butte and Carmel $=$ almond leaf scorch (ALS) resistant; Peerless and Sonora= ALS susceptible. Error bars represent one standard error and $n=4$ except for November 2007 and January 2008, where $n=2$. No significant $\mathrm{pH}$ differences were found between resistant and susceptible cultivars during winter months.

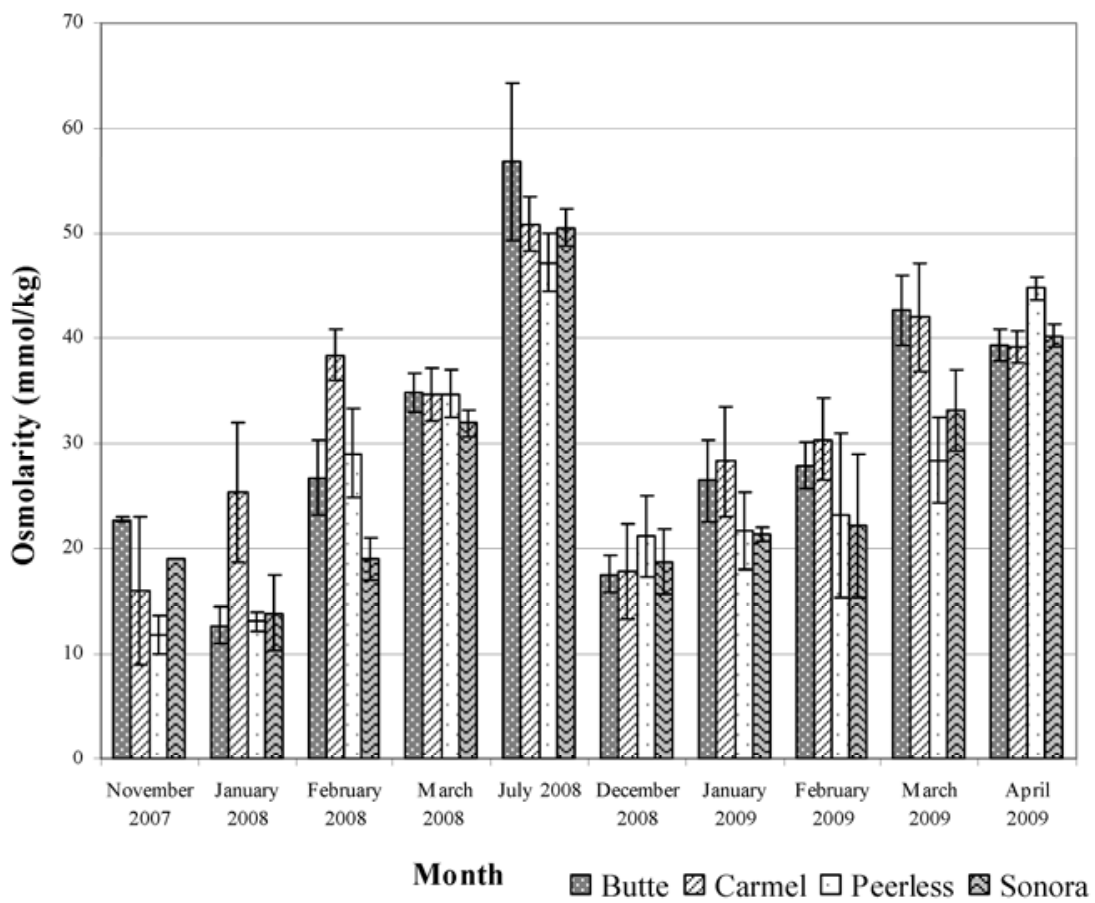

Fig. 2. Average osmolarity of almond xylem fluid from four almond cultivars measured in mmol/kg. Butte and Carmel = almond leaf scorch (ALS) resistant; Peerless and Sonora= ALS susceptible. Months sampled included winter and spring 2007 to 2009, including July 2008. Error bars represent standard error, $n=4$, except November 2007 and January 2008 where $n=2$. No significant differences in osmolarity were found between resistant and susceptible almond cultivars in any specific month but osmolarity increased across all cultivars from winter to spring and into summer. 
with higher glucose and fructose concentrations in individual trees (data not shown). The only statistically significant difference in osmolarity was between Carmel and Sonora in February 2008, when Carmel was higher than Sonora $(P<0.0158)$. Differences in osmolarities during winter and spring 2008-09 were not statistically significant.

Concentrations of sugars, minerals, and organic acids. Glucose and fructose were the most abundant sugars in xylem fluid

Table 1. Sugar and mineral concentrations of four almond cultivars ${ }^{x}$

\begin{tabular}{|c|c|c|c|c|}
\hline \multirow[b]{3}{*}{ Sugars, minerals, month ${ }^{\mathrm{z}}$} & \multicolumn{4}{|c|}{ Concentration $(\mu \mathrm{M})^{\mathrm{y}}$} \\
\hline & \multicolumn{2}{|c|}{ ALS-resistant cultivars } & \multicolumn{2}{|c|}{ ALS-susceptible cultivars } \\
\hline & Butte & Carmel & Peerless & Sonora \\
\hline \multicolumn{5}{|l|}{ Glucose } \\
\hline January & $2,775 \pm 44$ & $5,900 \pm 877$ & $394 \pm 278$ & $2,609 \pm 167$ \\
\hline February & $2,076 \pm 94$ & $3,425 \pm 333$ & $3,541 \pm 117$ & $2,059 \pm 278$ \\
\hline March & $2,692 \pm 339$ & $3,464 \pm 1,177$ & $544 \pm 272$ & $1,443 \pm 167$ \\
\hline July & $3,824 \pm 427 \mathrm{ab}$ & $6,050 \pm 1,016 \mathrm{ab}$ & $3,025 \pm 655 \mathrm{~b}$ & $5,878 \pm 1,021 \mathrm{a}$ \\
\hline \multicolumn{5}{|l|}{ Fructose } \\
\hline January & $2,015 \pm 100$ & $4,468 \pm 466$ & $2,531 \pm 33$ & $2,292 \pm 255$ \\
\hline February & $2,309 \pm 844$ & $2,342 \pm 389$ & $2,503 \pm 483$ & $1,127 \pm 155$ \\
\hline March & $1,837 \pm 250$ & $2,770 \pm 488$ & $2,265 \pm 144$ & $827 \pm 167$ \\
\hline July & $3,142 \pm 355$ & $4,829 \pm 938$ & $2,437 \pm 472$ & $5,262 \pm 1,182$ \\
\hline \multicolumn{5}{|l|}{ Sucrose } \\
\hline January & $161 \pm 85$ & $429 \pm 225$ & $169 \pm 61$ & $53 \pm 38$ \\
\hline February & $114 \pm 15$ & $111 \pm 18$ & $67 \pm 15$ & $50 \pm 12$ \\
\hline March & ND & $85 \pm 9$ & $29 \pm 6$ & $44 \pm 18$ \\
\hline July & $196 \pm 12 b c$ & $435 \pm 47 a$ & $342 \pm 120 \mathrm{c}$ & $283 \pm 18 b$ \\
\hline \multicolumn{5}{|l|}{ Magnesium } \\
\hline January & $1,111 \pm 123$ & $987 \pm 247$ & $782 \pm 206$ & $823 \pm 247$ \\
\hline February & $1,357 \pm 123$ & $1,152 \pm 82$ & $1,481 \pm 123$ & $1,645 \pm 165$ \\
\hline March & $905 \pm 82$ & $658 \pm 41$ & $740 \pm 41$ & $617 \pm 82$ \\
\hline July & $370 \pm 41 \mathrm{~b}$ & $782 \pm 41 a b$ & $658 \pm 123 a b$ & $946 \pm 82 \mathrm{a}$ \\
\hline \multicolumn{5}{|l|}{ Calcium } \\
\hline January & $1,072 \pm 150$ & $948 \pm 200$ & $848 \pm 249$ & $648 \pm 100$ \\
\hline February & $1,671 \pm 249$ & $1,546 \pm 100$ & $1,696 \pm 200$ & $1,696 \pm 249$ \\
\hline March & $898 \pm 200$ & $673 \pm 75$ & $673 \pm 50$ & $524 \pm 100$ \\
\hline July & $698 \pm 50$ & $1,122 \pm 75$ & $1,047 \pm 100$ & $1,172 \pm 100$ \\
\hline
\end{tabular}

Table 2. Organic acid concentrations in xylem fluid from four almond cultivars during months sampled, January to July $2008^{\mathrm{x}}$

\begin{tabular}{|c|c|c|c|c|}
\hline \multirow[b]{3}{*}{ Organic acid, month ${ }^{\mathrm{z}}$} & \multicolumn{4}{|c|}{ Concentration $(\mu \mathrm{M})^{\mathrm{y}}$} \\
\hline & \multicolumn{2}{|c|}{ ALS-resistant cultivars } & \multicolumn{2}{|c|}{ ALS-susceptible cultivars } \\
\hline & Butte & Carmel & Peerless & Sonora \\
\hline \multicolumn{5}{|l|}{ Citric } \\
\hline January & $553 \pm 48$ & $611 \pm 40$ & $370 \pm 30$ & $538 \pm 113$ \\
\hline February & $891 \pm 117$ & $562 \pm 83$ & $832 \pm 76$ & $961 \pm 151$ \\
\hline March & $476 \pm 53$ & $373 \pm 60$ & $389 \pm 56$ & $382 \pm 114$ \\
\hline July & $933 \pm 353$ & $2,192 \pm 1,186$ & $1,271 \pm 464$ & $869 \pm 263$ \\
\hline \multicolumn{5}{|l|}{ Oxalic } \\
\hline January & $13 \pm 10$ & $21 \pm 1$ & $1 \pm 1$ & $5 \pm 5$ \\
\hline February & $5 \pm 2$ & $8 \pm 5$ & $8 \pm 5$ & $8 \pm 5$ \\
\hline March & $6 \pm 6$ & $2 \pm 0.28$ & $4 \pm 3$ & $8 \pm 5$ \\
\hline July & $3 \pm 0.15$ & $7 \pm 7$ & $7 \pm 5$ & $15 \pm 1$ \\
\hline \multicolumn{5}{|l|}{ Tartaric } \\
\hline January & $13 \pm 2 b$ & $53 \pm 3 a$ & $10 \pm 10 \mathrm{~b}$ & $45 \pm 5 \mathrm{a}$ \\
\hline February & $6 \pm 4$ & $7 \pm 4$ & ND & $5 \pm 5$ \\
\hline March & $14 \pm 6$ & $14 \pm 6$ & $6 \pm 5$ & ND \\
\hline July & ND & $7 \pm 3$ & ND & $9 \pm 1$ \\
\hline \multicolumn{5}{|l|}{ Malic } \\
\hline January & $711 \pm 110$ & $1,316 \pm 588$ & $603 \pm 128$ & $658 \pm 258$ \\
\hline February & $862 \pm 79$ & $629 \pm 142$ & $648 \pm 110$ & $567 \pm 139$ \\
\hline March & $388 \pm 39$ & $793 \pm 164$ & $621 \pm 66$ & $377 \pm 127$ \\
\hline July & $856 \pm 15$ & $1,320 \pm 130$ & $1,054 \pm 87$ & $1,123 \pm 122$ \\
\hline \multicolumn{5}{|l|}{ Malonic } \\
\hline January & $75 \pm 75$ & $198 \pm 28$ & N.D \pm & $50 \pm 50$ \\
\hline February & $43 \pm 26$ & $25 \pm 25$ & $64 \pm 5$ & $40 \pm 27$ \\
\hline March & $10 \pm 6$ & $25 \pm 18$ & $27 \pm 16$ & $16 \pm 16$ \\
\hline July & $33 \pm 33$ & $52 \pm 26$ & $116 \pm 58$ & $57 \pm 19$ \\
\hline
\end{tabular}

${ }^{\mathrm{x}}$ Monthly averages followed by dissimilar letters are significantly different $(P=0.05)$. Pairwise comparisons were made between cultivars for each month sampled using a repeated measures analysis of variance and least squared means adjustment for Tukey's highly significant difference.

${ }^{\text {y }} \mathrm{ALS}=$ almond leaf scorch. Averages \pm standard error, $n=4 ; \mathrm{ND}=$ not detectable.

z January, $n=2$. 
during the months analyzed. All sugars had the highest concentrations in July 2008. Magnesium and calcium concentrations were similar for all cultivars each month (Table 1).

Citric and malic acids were the most abundant organic acids in almond xylem fluid (Table 2). Tartaric and oxalic acids made up only a small proportion $(<10 \%)$ of the total organic acid concentrations. None of the organic acids were significantly different among almond cultivars in any individual month, except for tartaric acid in January 2008, when Carmel had a significantly higher concentration than Butte or Sonora $(P<0.0009$ and 0.0193 , respectively).

Total phenolic concentrations. Total phenolic compounds were significantly higher in resistant cultivars for at least 1 month in both winters analyzed. Furthermore, we observed an overall trend that concentrations of phenolic compounds were higher in the resistant cultivars over winter months. During the spring and summer months that were sampled, all four cultivars had similar phenolic concentrations. In February 2008, xylem fluid from the resistant cv. Butte had a significantly higher phenolic concentration than Peerless and Sonora $(P<0.0357$ and 0.0138 , respectively; Fig. $3 \mathrm{~A})$. In the same month, phenolic compound concentration in xylem fluid collected from Carmel was numerically higher than Sonora but was not statistically different $(P<0.0819)$. In addition, xylem fluid from Carmel in January 2008 had comparatively higher phenolic compounds than Peerless and Sonora, although the difference was not statistically significant $(P<0.0922$ and 0.1330 , respectively).

Over the next winter, the trend continued such that total phenolic compounds were higher in cvs. Carmel and Butte in November 2008 to February 2009, although not all results were statistically significant (Fig. 3B). Butte in December 2008 had a significantly higher phenolic compound concentrations than Sonora $(P<$ 0.0127). Subsequently, in January 2009, Carmel had the highest total phenolic compounds measurement, $233 \mu \mathrm{g} / \mathrm{ml} \mathrm{GAE}$. In this month, cv. Carmel had significantly higher phenolic compound concentration than the other cultivars, including Butte $(P<$ $0.0155)$, Peerless, and Sonora $(P<0.001)$. Additionally, Butte in January 2009 was significantly higher than Peerless $(P<0.0202)$ but not Sonora.

Xylem vessel measurements. Spring vessels in cv. Peerless averaged 2,858 $\mu \mathrm{m}^{2}$ and Butte spring vessels were, on average, $3,000 \mu \mathrm{m}^{2} ; t$-test comparisons of these means showed they are not significantly different. Both cultivars had the same average summer vessel area, $400 \mu \mathrm{m}^{2}$. Thus, spring vessels were about 10-fold larger than summer vessels. Both Butte and Peerless trees had more abundant summer vessels than spring vessels,
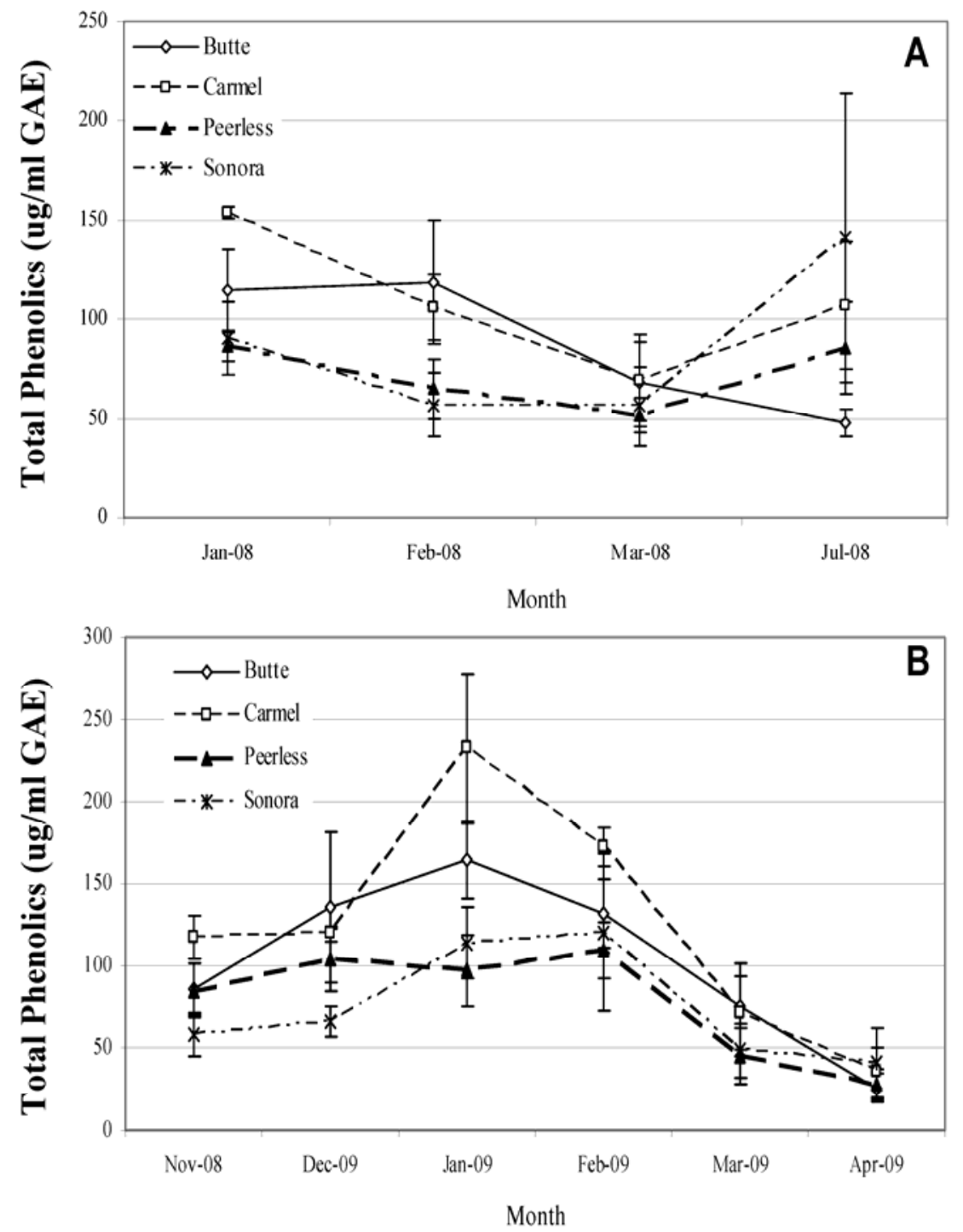

Fig. 3A and B, Total phenolic compound concentrations in almond xylem fluid from Butte, Carmel, Peerless, and Sonora cultivars as measured in gallic acid equivalents (GAE). Error bars represent one standard deviation, $n=4$, except for January 2008, when $n=2$. There is a trend for Butte and Carmel (almond leaf scorch [ALS]-resistant cultivars) to have higher polyphenolic concentrations than Peerless and Sonora (ALS-susceptible cultivars) over winter months. Average total phenolics were significantly higher in one resistant cultivar compared with susceptible cultivars in February 2008, December 2008, and January $2009(P<0.05)$. In January 2009, Carmel in had the highest polyphenolic measurement, $233 \mu \mathrm{g} / \mathrm{ml}$ GAE. 
although vessel numbers per unit area of cross-section were not quantified.

\section{Discussion}

Over winter months, we observed an overall trend for Butte and Carmel almond cultivars to have higher concentrations of phenolic compounds than Peerless and Sonora. Because antibacterial properties of phenolic compounds are well documented, higher phenolic concentrations within xylem fluid of ALS-resistant cultivars could decrease $X$. fastidiosa survival over the winter. Plant phenolic compounds are a structurally diverse group of compounds that all contain modifications of the base phenol. Phenolic compounds are secondary metabolites that play a role in plant defense, while polyphenolic lignins and tannins are structural components of cell walls. Phenolic compounds extracted from raspberry and cloudberry had antimicrobial activity against two strains of Escherichia coli and one strain of Salmonella enterica (29). In that study, however, antimicrobial activity was observed in plants with phenolics concentrations approximately 1,000-fold higher than our measurements from almond xylem fluid (29). Maddox et al. (24) tested a variety of phenolic compounds in vitro to determine which ones could inhibit $X$. fastidiosa growth. Two grape and two almond strains of $X$. fastidiosa were tested. The phenolic catechol required the lowest minimum concentration to inhibit $X$. fastidiosa growth at $100 \mu \mathrm{M}$. However, caffeic acid, gallic acid, quercitin, resveratrol, and catechin also inhibited $X$. fastidios $a$ growth at concentrations of 200 to $400 \mu \mathrm{M}$. The highest total amount of phenolic compound measured in our study was found for cv. Carmel in January 2009 at $233 \mu \mathrm{g} / \mathrm{ml}$. If this value is converted to a micromolar equivalent of gallic acid, the result is $1,370 \mu \mathrm{M}$ GAE, which is 3.4 times more concentrated than the amount of gallic acid needed to observe $X$. fastidiosa inhibition in the Maddox experiment. Milbury et al. (25) isolated several different phenolic compounds from almond skins and kernels, including flavonoids such as catechins, kaempferols, quercitins, and isohamnetins. In addition, they found that Nonpareil, Price, Carmel, and Butte had the highest total kernel per skin polyphenolic compounds, all above $200 \mu \mathrm{g} / \mathrm{g}$ GAE. Identifying the specific phenolic compounds in almond xylem fluid would be the next step toward determining which compounds are affecting $X$. fastidiosa over the winter.

Measurements of xylem fluid $\mathrm{pH}$, osmolarity, and concentrations of sugars, minerals, and organic acids did not show significant differences between resistant and susceptible almond cultivars over the winter months of 2007-08 or March and July 2008. The results suggest that these components of xylem fluid chemistry are not contributing to lower $X$. fastidiosa overwintering survival. Glucose and fructose had higher concentrations in xylem fluid than sucrose, and these sugars likely contributed to higher osmolarity measurements in spring and summer. Increased glucose concentrations decreased $X$. fastidiosa cell aggregation in artificial defined medium (22) but sugar concentrations over the winter months were not significantly different between ALS-resistant and ALSsusceptible cultivars. Nor were calcium and magnesium concentrations different, and these elements have also been shown to affect $X$. fastidiosa aggregation and biofilm formation and could also affect survival within the xylem (23). Malic and citric acids were the most abundant organic acids, which is similar to results of Andersen et al. (5) quantification of organic acids in plum (Prunus salcinia) xylem fluid.

Our analysis of cross-sectional areas of almond xylem vessels did not show differences between ALS-resistant and ALSsusceptible cultivars. However, other anatomical differences have been found between grapevine species and cultivars that are comparatively resistant and susceptible to PD. These anatomical differences may affect the systemic colonization of $X$. fastidiosa within the plant. Labavitch et al. (20) showed that xylem vessel arrangements were different between grapevine cultivars that were more resistant or tolerant to PD compared with susceptible cultivars. Resistant types had a larger proportion of xylem vessels arranged in chains compared with susceptible cultivar vessels, which were predominantly solitary. Furthermore, Labavitch et al. (21) found that xylem vessel pit membrane polysaccharide compositions were different between PD-susceptible grapevine Vitis vinifera 'Chardonnay' and PD-resistant species Muscadinia rotundifolia. Although our studies showed no significant differences between xylem diameters for susceptible and resistant almond cultivars, indepth studies of xylem arrangement and composition between almond cultivars need to be conducted.

Current management for ALS is primarily removal of infected trees. Because tree-to-tree spread is not prevalent, infected trees may be removed when the nut yield declines to an unprofitable economic level (33). It is possible that pruning out newly infected branches could prevent losing the entire tree; however, these studies have not been completed (15). Our finding that total phenolic compounds were higher in the xylem fluid of resistant Butte and Carmel cultivars suggests a possible role of phenolic compounds in $X$. fastidiosa resistance. Exogenous application of compounds that elevate the synthesis or activity of enzymes that mediate plant phenolic metabolism such as phenylalanine ammonia lyase may be a potential tool for managing $X$. fastidiosa infection in almond.

\section{Acknowledgments}

Financial support was provided by the Almond Board of California. We thank T. Rost at University of California, Davis for microscopy assistance.

\section{Literature Cited}

1. Abramoff, M. D., Magelhaes, P. J., and Ram, S. J. 2004. Image processing with ImageJ. Biophoton. Int. 11:36-42.

2. Aldrich, J. H., Gould, A. B., and Martin, F. G. 1992. Distribution of Xylella fastidios $a$ within roots of peach. Plant Dis. 76:885.

3. Almeida, R. P. P., and Purcell, A. H. 2003. Biological traits of Xylella fastidiosa strains from grapes and almonds. Appl. Environ. Microbiol. 69:7447-7452.

4. Andersen, P. C., and Brodbeck, B. V. 1989. Chemical composition of xylem exudate from bleeding spurs of Vitis rotundifolia Noble and Vitis hybrid Suwannee in relation to pruning date. Am. J. Enol. Vitic. 40:155-160.

5. Andersen, P. C., Brodbeck, B. V., and Mizell, R. F., III.1995. Water stress and nutrient solution-mediated changes in water relations and amino acids, organic acids, and sugars in xylem fluid of Prunus salicina and Lagerstroemia indica. J. Am. Soc. Hortic. Sci. 120:36-42.

6. Andersen, P. C., Brodbeck, B. V., Oden, S., Shriner, A., and Leite, B. 2007. Influence of xylem fluid chemistry on planktonic growth, biofilm formation and aggregation of Xylella fastidiosa. FEMS Microbiol. Lett. 274:210-217.

7. Andersen, P. C., Leite, B., and Ishida, M. L. 2004. Xylem chemistry mediation of resistance to Pierce's disease. Pages 141-144 in: Proc. Pierce's Disease Res. Symp. California Department of Food and Agriculture, Sacramento.

8. Bi, J. L., Dumenyo, C. K., Hernandez-Martinez, R., Cooksey, D. A., and Toscano, N. C. 2007. Effect of host plant xylem fluid on growth, aggregation, and attachment of Xylella fastidiosa. J. Chem. Ecol. 33:493-500.

9. Brodbeck, B. V., Andersen, P. C., and Mizell, R. F., III. 1996. Utilization of primary nutrients by the polyphagous xylophage, Homalodisca coagulata, reared on a single host species. Arch. Insect Biochem. Physiol. 32:65-83.

10. Brodbeck B.V., Andersen, P.C., Mizell, R. F., III, Oden, S. 2004. Comparative nutrition and developmental biology of xylem-feeding leafhoppers reared on four genotypes of Glycine max. Environ. Entomol. 33:165-173

11. Cao, T., Connell, J. H., Wilhelm, M., and Kirkpatrick, B. C. 2011. Influence of inoculation date on the colonization of Xylella fastidiosa and the persistence of almond leaf scorch among almond cultivars. Plant Dis. 95:158-165.

12. Chen, J., Groves, R., Civerolo, E. L., Viveros, M., Freeman, M., and Zheng, Y. 2005. Two Xylella fastidiosa genotypes associated with almond leaf scorch disease on the same location in California. Phytopathology 95:708714.

13. Davis, M. J., Thomson, S. V., and Purcell, A. H. 1980. Etiological role of the xylem limited bacterium causing Pierce's disease in almond (Prunus amygdalus) leaf scorch. Phytopathology 70:472-475.

14. Feil, H., and Purcell, A. H. 2001. Temperature-dependent growth and survival of Xylella fastidiosa in vitro and in potted grapevines. Plant Dis. 85:1230-1234.

15. Groves, R. L., Chen, J., Civerolo, E. L., Freeman, M. W., and Viveros, M. A. 2005. Spatial analysis of almond leaf scorch disease in the San Joaquin Valley of California: factors affecting pathogen distribution and spread. Plant Dis. 89:581-589.

16. Haviland, D. H., and. Viveros, M. A. 2005. Surveys for almond leaf scorch in Kern County, CA, and implications on pruning as a tool for management. In: Annual Research Report, Almond Board of California.

17. Hendson, M., Purcell, A. H., Chen, D., Smart, C., Guilhabert, M., and Kirkpatrick, B. 2001. Genetic diversity of Pierce's disease strains and other pathotypes of Xylella fastidiosa. Appl. Environ. Microbiol. 67:895-903. 
18. Hopkins, D. L. 1989. Xylella fastidiosa: xylem-limited bacterial pathogen of plants. Annu. Rev. Phytopathol. 27:271-290.

19. Kirkpatrick, B. C., and Meyer, M. M. 2004. Identification of mechanisms mediating cold therapy of Xylella fastidiosa-infected grapevines. Pages 352-354 in: Proc. Pierce's Disease Res. Symp. California Department of Food and Agriculture, San Diego.

20. Labavitch, J., and Sun, Q. 2008. Do cell wall structures limit Xylella fastidiosa distribution in inoculated, Pierce's disease susceptible and resistant grapevines? Pages 223-227 in: Proc. 2008 Pierce's Disease Res. Symp. California Department of Food and Agriculture, San Diego.

21. Labavitch, J., Sun, Q., Lindow, S., Walker, A., and Lin, H. 2009. Do cell wall structures limit xylella fastidiosa distribution in inoculated, Pierce's disease susceptible and resistant grapevines? Pages 174-180 in: Sacramento, CA.

22. Leite, B., Anderson, P. C., and Ishida, M. L. 2004. Colony aggregation and biofilm formation in xylem chemistry-based media for Xylella fastidiosa. FEMS Microbiol. Lett. 230:283-290.

23. Leite, B., Ishida, M. L., Brodbeck, B. V., Marques, L., Olson, M. E., Braga, M. R., and Andersen, P. C. 2004. Calcium availability influences aggregation and adhesion of Xylella fastidiosa, the causal agent of the Pierce's disease in grapes. (Abstr.) Phytopathology 94:S59.

24. Maddox, C. E., Laur, L. M., and Tian, L. 2010. Antibacterial activity of phenolic compounds against the phytopathogen Xylella fastidiosa. Curr. Microbiol. 60:53-58

25. Milbury, P. E., Chen, C. Y., Dolnikowski, G. G., and Blumberg, J. B. 2006. Determination of flavonoids and phenolics and their distribution in almonds. J. Agric. Food Chem. 54:5027-5033.

26. Mircetich, S. M., Lowe, S. K., Moller, W. J., and Nyland, G. 1976. Etiology of almond leaf scorch disease and transmission of the causal agent. Phytopathology 66:17-24.

27. Purcell, A. H. 1980. Almond leaf scorch leafhopper and spittlebug vectors. J. Econ. Entomol. 73:834-838.

28. Purcell, A. H. 1997 Xylella fastidiosa, a regional problem or global threat? J. Plant Pathol. 79:99-105.

29. Puupponen-Pimia, R., Nohynek, L., Meier, C., Kahkonen, M., Heinonen, M., Hopia, A., and Oksman-Caldentey, K. M. 2001. Antimicrobial properties of phenolic compounds from berries. J. Appl. Microbiol. 90:494-507.

30. Sanborn, R. R., Mircetitch, S. M., Nyland, G., and Moller, W. J. 1974 "Golden death" a new leaf scorch threat to almond growers. Calif. Agric. 28:4-5.

31. Shapland, E. B., Daane, K. M., Yokota, G. Y., Wistrom, C., Connell, J. H., Duncan, R. A., and Viveros, M. A. 2006. Ground vegetation survey for Xylella fastidiosa in California almond orchards. Plant Dis. 90:905-909.

32. Sherald, J. L., and Kostka, S. J. 1992. Bacterial leaf scorch of landscape trees caused by Xylella fastidiosa. J. Arboric. 18:57-63.

33. Sisterson, M. S., Chen, J., Viveros, M. A., Civerolo, E. L., Ledbetter, C., and Groves, R. L. 2008. Effects of almond leaf scorch disease on almond yield: implications for management. Plant Dis. 92:409-414.

34. Sisterson, M. S., Thammiraju,, S. R., Daane, K., and Groves, R. L. 2008 Assessment of the role of alfalfa in the spread of Xylella fastidiosa in California. (Abstr.) Phytopathology 98:S147.

35. Slinkard, K., and Singleton, V. L. 1977. Total phenol analysis-automation and comparison with manual methods. Am. J. Enol. Vitic. 28:49-5

36. Waterhouse A L. 2002. Unit I1.1: phenolic compounds: determination of total phenolics, Pages 1-4 in: Current Protocols in Food Analytical Chemistry. R. E. Wrolstad, ed. John Wiley \& Sons, New York. 